\title{
血液透析中の酢酸の影響と重炭酸透析について
}

\author{
水谷洋子山本忠司野崎寛爾山川真岸本武利* \\ 前川 正 信* \\ 仁真会白鷺病院 大阪市立大学泌尿器科*
}

(昭和 55 年 7 月 29 日受付)

Key words: Acetate dialysate, Bicarbonate dialysate, Acetate, Acetate transfer rate, Asymptomatic dialysis

〈要旨〉

酶酸の添加された重炭酸透析液について，安定性と酢酸の生体への移行量測定を行ない，また重炭酸透析と酢酸透 析を比較することにより，重炭酸透析の臨床的効果と酢酸透析の生体の影響を検索した。

対象は 74 名の慢性透析患者で, 研究は $9 \mathrm{mmol} / l$ の酢酸を含む重炭酸透析液の多人数用供給装置での安定性、重炭 酸透析と酢酸透析の主化学検査および愁訴発現頻度による長期臨床比較, 2 重盲検交差試験による短期臨床比較, 酶 酸の生体移行量測定に分けて施行された。

その結果, 重炭酸透析液の $\mathrm{pH}, \mathrm{PCO}$ は安定しており, Ca 濃度に関しても特に問題となることはなかった。長期臨 床比較では重炭酸透析に生化学検査の改善を認め, 酷酸透析に愁訴発現を高率で認めた。 2 重盲検交差試験では重炭 酸透析を䣷酸透析に転換したことによク，61％の患者に何らかの愁訴発現を観察し，21％の患者はその症状が激しく

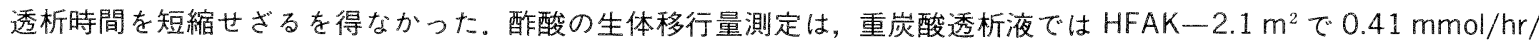
kgであった。

以上のことょり, 重炭酸透析に添加された少量の酷酸は, 透析液, 生体側共に良好な緩衝剤となり, 生体で充分代 謝できる量であることが示された。また酢酸透析は透析中の不快な愁訴発現に関連があり，無症候透析という点で重 炭酸透析よりすぐれていることが示された。重炭酸透析は生化学検査でも酶酸透析と同等もしくはそれ以上の成績が 得られ，32か月間の使用にも副作用と思われることは認めなかった。

\section{Studies of bicarbonate dialysate and effects of acetate in hemodialysis}

Yoko Mizutani, Tadashi Yamamoto, Kanji Nozaki, Makoto Yamakawa, Taketoshi Kishimoto*, Masanobu Maekawa*

The Kidney Center, Shirasagi Hospital, Osaka. The Department of Urology, Osaka Cit. Univ. Med. Sch*.

Bicarbonate ion is not stable in the neutral dialysate and forms complex salt in presence of calcium and magnesium ions. We have prescribed bicarbonate containing dialysate (bicarbonata dialysate) and developed the bicarbonate dialysate central supply system. This bicarbonate dialysate contains about $3 \mathrm{mmol} / l$ acetic acid and $6 \mathrm{mmol} / l$ sodium acetate to stabilize $\mathrm{pH}$ and $\mathrm{PCO}_{2}$. Estimation of the stability of bicarbonate dialysate on the central supply system was examined and comparative studies between hemodialysis with acetate containing dialysate (Ac-D) and with bicarbonate dialysate (BC-D) were performed in 74 patients. Thirty one patients were studied to compare the clinical data and the incidence of morbidity between Ac-D and BC-D. In 56 patients, the double blind-cross over tests were carried out between $A C-D$ and $B c-D$. The rate of acetate transfered from dialysate to blood was estimated in 21 patients.

Results were followed as : 1) $\mathrm{pH}$ and $\mathrm{PCO}_{2}$ of the bicarbonate dialysate were adjusted and kept optimal values. Accordingly, concentration of soluble calcium in the bicarbonate dialysate were stabilized. 2) The improvements of clinical data and abating of morbidity during hemodialysis were obtained when Ac-D was changed to Bc-D. 3) In the double blind-cross over tests, additional symptoms were developed in 34 patients $(61 \%)$ and 12 patients $(21 \%)$ were not able to continue the hemodialysis owing to their severe symptoms when BC-D was substituted 
by Ac-D. 4) The rate of transfered acetate was calculated at $0.41 \mathrm{mmol} / \mathrm{hr} / \mathrm{kg}$ (mean) on Bc-D and $3.47 \mathrm{mmol} /$ $\mathrm{hr} / \mathrm{kg}$ (mean) on AC-D when HFAK- $1.1 \mathrm{~m}^{2}$ was used. A small amount of acetate contained in the bicarbonate dialysate $(9 \mathrm{mmol} / \boldsymbol{l})$ was utilized completely with no increase of serum acetate level or symptoms. 5) There were no side effects found during 32 months's maintenance Bc-D.

It is possible from these data that the high rate of transfered acetate is one of causes inducing morbidity during $A c-D$, and that less morbidity of Bc-D leads to more efficient hemodialysis resulted in improvements of clinical data. According to our statistics, about $20 \%$ of whole hemodialysis patients are intolerance to Ac-D and about $60 \%$ of them are necessary of BC-D to maintain with no symptoms during hemodialysis.

$\mathrm{BC}-\mathrm{D}$ should be a choice when short time dialysis are tried with high performance dialyzer.

\section{緒言}

透析液の緩衝剤としては重炭酸 soda の使用が最も望 ましいが, 重炭酸 soda が透析液中で不安定であること から, 緩衝剤には酢酸 soda が使用され, 酰酸 sodaを含 んだ透析液 (以下酢酸透析液) が広く用いられてきた。 しかし血液浄化法が進歩する中でまた, 透析困難な症例 が増加し，その一因として酢酸 soda の影響が報告され るようになった ${ }^{12)}$.こうしたことから我々は, 緩衝郕とし て主に重炭酸 soda 含む透析液 (以下重炭酸透析液) の 多人数用供給装置を試作し，これを用いて重炭酸透析液 の安定性を検索し，長期にわたって臨床的に使用したの で報告する。

\section{方法}

\section{1 対象}

白鷺病院に㧈いて腎不全のため血液透析を受けている 74 例の患者について検討した。その内わけは男子 41 例, 女子 33 例, 年齢 19 69 歳 (平均 42.4 歳), 透析期間 3 １10 か月（平均 44.4 か月）で，重篤な合併症のある患 者は含まれていない(Table 1)。これらの 74 例を 3 群に 分けた。A群は Table 1 の*印を付した 31 例で男子 16 例, 女子 15 例, 年齢 $27 \sim 57$ 歳 (平均 40.2 歳), 透析期 間 32 110 加 (平均 61.1 加) で酶酸透析液による透 析（以下酢酸透析）を 15 81 か月 (平均 33.8 か月) 受 けた後，重炭酸透析液に上る透析（以下重炭酸透析）に 移行し 15〜30 か月（平均 27.3 か月）経過したものであ る。この酷酸透析扔よび重炭酸透析の実施期において臨 床検查成績と愁訴発現頻度の比較をした。B群は Table 1 の患者番号 $1 \sim 56$ の 56 例, 男子 29 例, 女子 27 例, 年 齢 19 64 歳 (平均 42.6 歳), 透析期間 $6 \sim 110$ か月 (平 均 43.0 か月) で重炭酸透析を 6 ～30 か月（平均 22.3 か 月）間継続して受けており，この重炭酸透析の実施期に 1 回に限り 2 重盲検下で酷酸透析を施行されたものであ る.C群は Table $1 *$ 印を付した 21 例, 男子 15 例, 女 子 6 例, 年齢 $26 \sim 69$ 歳(平均 45.4 歳), 透析期間 $3 \sim 68$ か月 (平均 40.0 か月) で酢酸透析と重炭酸透析において, 透析液から生体への酢酸移行量を測定したものである.

\begin{tabular}{|c|c|c|c|c|c|c|c|c|c|c|c|c|c|}
\hline Patie & & Agre & Sex & P.D & $A C-D$ & $B C-D$ & & tient A & Age : & Sex & P.D & $A C-D$ & $\mathrm{BC}-1$ \\
\hline 1 & \# & 64 & M & is & 0 & 17 & 38 & T.K" & 42 & M & $\mathrm{CrN}$ & 10 & 19 \\
\hline 2 & & 40 & $M$ & $\mathrm{CGN}$ & 37 & 29 & 39 & $M \cdot K^{*}$ & 35 & M & $\operatorname{CliN}$ & 37 & 26 \\
\hline 3 & & 31 & M & COM & 40 & 29 & 40 & $s . s^{*}$ & 37 & M & $\operatorname{CGN}$ & 34 & 29 \\
\hline 4 & & 27 & $\mathrm{~F}$ & $\operatorname{CGN}$ & 36 & 22 & 41 & S.T $T^{*}$ & 39 & M & $\mathrm{CGN}$ & 31 & 29 \\
\hline 5 & * & 41 & M & $\mathrm{MH}$ & 47 & 24 & 42 & $K \cdot T^{\#}$ & 49 & M & $\mathrm{CGN}$ & 43 & 23 \\
\hline 6 & * & 41 & M & $\mathrm{MH}$ & 40 & 29 & 43 & $0.0^{*}$ & 47 & M & $\operatorname{CGN}$ & 0 & 19 \\
\hline 7 & & 34 & M & $\operatorname{CoN}$ & 3 & 29 & 44 & $S \cdot H^{* \#}$ & 27 & M & $\mathrm{CCN}$ & 17 & 15 \\
\hline 8 & * & 49 & $\mathrm{~F}$ & $\mathrm{PN}$ & 15 & 30 & 45 & $T \cdot F^{*}$ & 38 & M & $\mathrm{T} \mathrm{B}$ & 48 & 29 \\
\hline 9 & & 65 & $\mathrm{~F}$ & P N & 22 & 20 & 46 & T.F & 56 & M & CGN & 0 & 19 \\
\hline 10 & * & 31 & $\mathrm{~F}$ & $\operatorname{CGN}$ & 26 & 25 & 47 & T.M ${ }^{*}$ & 31 & F & $\operatorname{CGN}$ & 22 & 29 \\
\hline 11 & & 28 & M & $\operatorname{ClN}$ & 0 & 26 & 48 & $K . Y^{*}$ & 31 & M & $\mathrm{CGN}$ & 37 & 29 \\
\hline 12 & & 48 & $M$ & $\mathrm{c} K$ & 7 & 26 & 49 & K.M & 45 & M & $\mathrm{CCN}$ & 19 & 29 \\
\hline 13 & & 40 & F & $\operatorname{CGN}$ & 0 & 18 & 50 & S.N & 45 & M & c K & 0 & 14 \\
\hline 14 & & 44 & $\mathrm{~F}$ & $\operatorname{CGN}$ & 34 & 26 & 51 & T.K & 36 & M & $\operatorname{CGN}$ & 10 & 15 \\
\hline 15 & * & 57 & $\mathrm{~F}$ & $\mathrm{P} \mathrm{N}$ & 18 & 27 & 52 & J.N & 47 & M & $\cos$ & 0 & 8 \\
\hline 16 & * & 39 & E & $\operatorname{CON}$ & 37 & 28 & 53 & $\mathrm{S.H}$ & 47 & F & P N & 0 & 7 \\
\hline 17 & * & 45 & $\mathrm{~F}$ & $\mathrm{CCN}$ & 18 & 29 & 54 & K.S & 59 & M & $\operatorname{CGN}$ & 0 & 7 \\
\hline 18 & & 40 & M & $\mathrm{CGN}$ & 16 & 21 & 55 & M.Y & 40 & M & $\operatorname{CgN}$ & 0 & 24 \\
\hline 19 & & 53 & F & $P \mathbb{N}$ & 0 & 8 & 56 & K.o & 45 & F & P N & 0 & 21 \\
\hline 20 & & 19 & F & C D & 40 & 8 & 57 & $M \cdot R^{\#}$ & 42 & M & $\operatorname{CGN}$ & 0 & 3 \\
\hline 21 & & 52 & $M$ & $\mathrm{CCN}$ & 0 & 21 & 58 & E.T ${ }^{*}$ & 37 & $\mathrm{~F}$ & $\mathrm{MH}$ & 36 & 30 \\
\hline 22 & & 35 & $\mathrm{~F}$ & DM & 0 & 6 & 59 & $H \cdot N^{* \#}$ & 44 & F & $\mathrm{CON}$ & 34 & 26 \\
\hline 23 & $*$ & 42 & $\mathrm{~F}$ & $\mathrm{CGN}$ & 27 & 31 & 60 & $T \cdot N^{*}$ & 46 & M & $\mathrm{CGN}$ & 24 & 29 \\
\hline 24 & $: \#$ & 60 & $F$ & $P N$ & 0 & 27 & Bi & $M, N^{*}$ & 42 & M & $\operatorname{CGN}$ & 24 & 29 \\
\hline 25 & & 32 & $\mathrm{~F}$ & $\mathrm{CGN}$ & 10 & 23 & 62 & K.F $F^{*}$ & 31 & F & $\mathrm{CGN}$ & 32 & 29 \\
\hline 26 & & 32 & $\mathrm{~F}$ & $\operatorname{CGN}$ & 0 & 21 & 63 & H.M ${ }^{*}$ & 51 & $M$ & $\operatorname{CGN}$ & 25 & 29 \\
\hline 27 & & 59 & F & P N & 0 & 16 & 64 & T. $\gamma^{*}$ & 36 & F & $\mathrm{CGN}$ & 16 & 29 \\
\hline 28 & * & 55 & $\mathrm{~F}$ & $P N$ & 15 & 23 & 65 & H. Y ${ }^{*}$ & 49 & M & $\mathrm{CGN}$ & 16 & 29 \\
\hline 29 & & 46 & $\mathrm{~F}$ & CGN & 39 & 19 & 66 & M.s" & 41 & M & $\operatorname{CoN}$ & 20 & 0 \\
\hline 30 & & 38 & $\mathrm{~F}$ & T B B & 30 & 29 & 67 & T.S" & 29 & M & $\operatorname{CGN}$ & 66 & 0 \\
\hline 31 & & 27 & F & $\mathrm{CGN}$ & 53 & 15 & 68 & E. $\tau^{\#}$ & 40 & $\mathrm{~F}$ & $\operatorname{CGN}$ & 60 & 0 \\
\hline 32 & & 53 & $\mathrm{~F}$ & P N & 41 & 28 & 69 & $\mathrm{~K} \cdot \mathrm{M}^{\#}$ & 26 & $M$ & $\mathrm{CGN}$ & 48 & 0 \\
\hline 33 & $\#$ & 53 & $M$ & $\mathrm{CGN}$ & 0 & 26 & 70 & H. $\mathrm{O}^{\#}$ & 40 & M & $\mathrm{CGN}$ & 60 & 0 \\
\hline 34 & & 49 & $\mathrm{~F}$ & $\mathrm{CON}$ & 0 & 19 & 71 & $\mathrm{~K} \cdot \mathrm{M}^{*}$ & 40 & M & CGN & 36 & 6 \\
\hline 35 & & 40 & M & $\operatorname{CGN}$ & 44 & 29 & 72 & $k \cdot T^{\#}$ & 69 & M & CGN & 58 & 10 \\
\hline 36 & & 34 & M & C $\mathrm{K}$ & 67 & 29 & 73 & $T_{0} T^{\# \prime}$ & 52 & F & $C D$ & 37 & 0 \\
\hline 37 & * & 47 & $F$ & $\mathrm{CGN}$ & 40 & 19 & 74 & Y.s & 37 & M & CGN & 29 & 6 \\
\hline
\end{tabular}

P.D : Primary disease, CGN : Chronic glomerulonephritis, o $K$ : Couty kidney PN : Pyelonephritis, D M : Diabetes mellitus, CD: Collagen disease MH : Malignant hypertension, NS : Nephrosclelosis, T B : Tuberculosis AC-D : Duration of acetace dialysis ( months)

$B C-D$ : Duration of bicarbonate dialysis (months)

Table. 1 Characteristics of the Study Patients

\section{2 透析方法}

透析液供給装置は, 重炭酸透析では我々が試作した 20 人用重炭酸透析液供給装置 ${ }^{3}$ (Figure 1), 酢酸透析液で は20人用透析液供給装置 (Draik Willock M-4009) を 使用した。重炭酸透析液はキンダリー AF 号（扶桑薬品 工業株式会社)，酶酸透析液はキンダリー GF 号 (同上) を使用した。その 35 倍希哷後の組成を Table 2 に示す。 透析は中空線維型人工腎臓 (以下 HFAK) $1.1 \mathrm{~m}^{2}$ を用い, 透析時間は週 3 回 5 時間, 透析液流量は $400 \mathrm{~m} / / \mathrm{min}$, 血 液流量は $200 \mathrm{~m} l / \mathrm{min}$ とし, 一部の患者には HFAK2.1 $\mathrm{m}^{2}$ を使用した。 


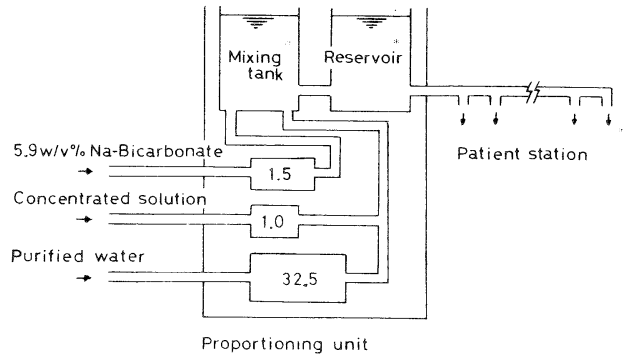

Fig. I Schematic diagram of bicarbonate dialysate-central supply system and site of measurement $(*)$

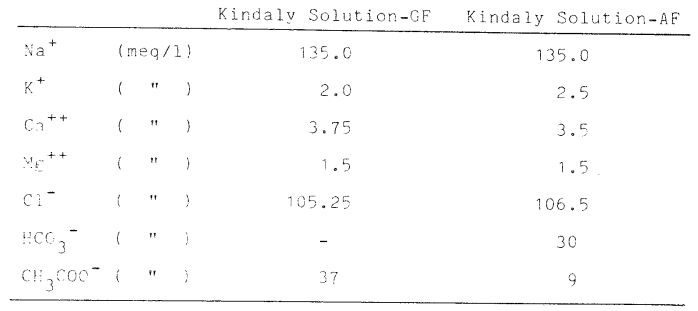

Table. 2 Composition of Dialysate

3 測定項目

1）重炭酸透析液の安定性

Figure 1 に示す供給装置中の reservoir と mixing tank および bed sideの透析液流路各部分において重炭 酸透析液 $\mathrm{pH}, \mathrm{PCO}_{2}, \mathrm{Ca}$ 濃度を 11 日間, 毎日計 18 回測定 した. $\mathrm{pH}, \mathrm{PCO}_{2}$ 測定にはCorning blood gas analyzer (M-165) を用い，Ca 濃度測定には自動分析装置（日立 706）を使用した。

2）臨床検査成績

A群の 31 例について, 重炭酸透析実施前 $3 \sim 12$ か月 (平均 6.1 か月) の酶酸透析，市上び実施後 $4 \sim 19$ か月 (平均 10.0 か月) の重炭酸透析の臨床検査成績を比較し た。また酷酸透析の実施期に 1 回，重炭酸透析の実施期 に 1 回，おの扔のの透析中（透析前，開始後 2 時間， 4 時間， 5 時間）に酸・塩基平衡を測定した。検查項目は 寸べて透析前值で, 毎回透析時に体重 $(\mathrm{BW})$, 除水量 $(\triangle \mathrm{BW})$, 血圧 $(\mathrm{BP})$, 尿素窒素 $(\mathrm{BUN})$, クレアチニン $(\mathrm{Cr})$, 尿酸 (UA), 血清電解質 $\mathrm{Na}, \mathrm{K}, \mathrm{Ca}, \mathrm{Cl}$, 無機り ン (iP), 総タンパタ (TP) を, また毎週 1 回, 赤血球 数 $(\mathrm{RBC})$, 白血球数 (WBC), 血色素量 $(\mathrm{Hb})$, ヘマト クリット (Ht) を, そして毎月 1 回, 血糖 (GLU), ト リグリセライド (TG), 総コレステロール (TC), 酵素 活性 LDH, DOT, GPT, Alp，および心胸比 (CTR) を 測定した。測定方法はBUN, Cr, Ca, ip, GOT, GPTに
関しては自動分析装置（日立 706） $\mathrm{Na} ， \mathrm{~K}$ は Corning flame photometer $430, \mathrm{Cl}$ は Chloride meter C-50 (Jooko), TP は SPR-T2 (Atago), RBC, WBC, Hb, Ht は Microcell counter CC-120 (Sysmex), LDH はリニア ネオ $3 \mathrm{~A}$ (シノテスト), Alp はAlp キット $\mathrm{N}$ (日商), 血 糖は Glucomesser direct (シノテスト)，TGはトリグラ 一ゼ D (ニッスイ)，TCは TCキット(日商)，酸・塩基 平衡に関しては Corning blood gas analyzer (M-165) をそれぞれ用いた。

3）愁訴発現頻度

A群の 31 例について 2) と同様に重炭酸透析実施前の 2251 回の酢酸透析，少よびその後実施した 4752 回の重 炭酸透析について，愁訴発現頻度を愁訴別に透析記録よ り集計し比較検討した。

4） 2 重盲検交差試験

B群の 56 例について，こ机ら患者はもとより，医療ス タッフにも全く知らしめることなく 1 回の透析に限り, 重炭酸透析液を酷酸透析液に変更することにより施行さ れた。またこの試験に扔いて両透析液の $\mathrm{Na}$ 濃度招よび 浸透圧には差のないようにした。交差試験終了後, 酢酸 透析施行時の補液量 (生食液), 愁訴の頻度を透析記録よ り集計した。また重炭酸透析施行時の補液量を交差試験 の前後 1 週間から平均し比較とした。透析終了後の患者 の状態は次回透析時に直接面接し，調査した。

5）酶酸移行量測定

C群の 21 例中 14 例について酢酸透析液を用い, HFAK $1.1 \mathrm{~m}^{2}$ ，5 時間透析を 14 回施行，HFAK2.1 m², 4 時間透析を 6 回施行，また 7 例には重炭酸透析液を用 い, HFAK1.1 m² 5 時間透析を 5 回, HFAK2.1 m²透析を 4 回それぞれ施行した。これらの透析に扔いて，透析膜 を介して透析液から生体に移行した酢酸の量を測定し た。また測定は，透析排液をすべて回収し，次式より算 出した。

総酢酸移行量 $=$ (総排液量 - 除水量 $) \times$

透析液酢酸濃度 - 総排液量 $\times$ 排液酶酸濃度

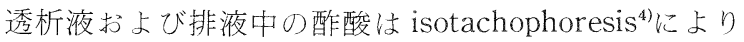
測定した。

以上，成績はすべて平均士標準偏差（s.d）で示し，そ の推計学的検討には $\mathrm{t}$-検定㧍よび $\mathrm{x}^{2}$ 一検定を用い, 危険 率 $5 \%$ 以下を有意とした。

\section{成績}

1 重炭酸透析液の安定性

透析液 $\mathrm{pH}$ は mixing tank で $7.20 \pm 0.06$, reservoir で $7.29 \pm 0.08$ と有意の上昇を示し, 以後 bed sideまで安 定した。 $\mathrm{PCO}_{2}$ 法 mixing tank で $67.0 \pm 12.3 \mathrm{mmHg}$, reservoir で $53.8 \pm 11.1 \mathrm{mmHg}$ と有意に減少し, 以後は 


\begin{tabular}{|c|c|c|c|c|}
\hline & Mixing tank & Reservoir & Bed & side \\
\hline $\begin{array}{l}\text { Zoncentration of } \\
\text { zalcium (mea/l) }\end{array}$ & $3.50(0.24)$ & $3.57(0.22)$ & 3.57 & $(0.14)$ \\
\hline $\mathrm{sH}$ & $7.20(0.06)$ & $7.29(0.08)^{*}$ & 7.26 & $(0.07)$ \\
\hline$(m i n g)$ & $67.0(12.3)$ & $53.8(11.1)^{*}$ & 54.9 & $(12.2)$ \\
\hline
\end{tabular}

Table. 3 Stability of Bicarbonate Dialysate on the Central Supply System

安定した.Ca 濃度は全流路における有意の濃度変化は認 められなかった（Table 3).

\section{2 臨床検查成績}

酢酸透析と重炭酸透析の比較では $\mathrm{BW}, \Delta \mathrm{BW}, \mathrm{Na}, \mathrm{K}$, Cl, iP, TP, WDC, Alp, TG, TC, GLUに差は認められな かった。しかし BUN は 93.8 から $87.3 \mathrm{mg} / \mathrm{d} l$ に, $\mathrm{Cr}$ は 13.8 から $13.2 \mathrm{mg} / \mathrm{d} l$ に, UA は 10.4 から $8.0 \mathrm{mg} / \mathrm{d} l$ と有 意に減少し, GOTは 28.7 から 22.6 unitに, GPT は 30 6 から 22.8 unit に, LDH は 319.7 から 273.6 unit に有意 の低下を示した。一方, RBCは $234 \times 10^{4} / \mathrm{mm}^{3}$ から $253 \times$ $10^{4} / \mathrm{mm}^{3}, \mathrm{Hb}$ が 8.0 から $8.4 \mathrm{~g} / \mathrm{d} l$, Ht が 22.9 から $24.8 \%$ とわずかながら有意の改善がみられた。CTR は 48.4 か ら $47.1 \%$ に, BP は収縮期圧で 133.5 から $125.2 \mathrm{mmHg}$ に, 拡張期圧で 79.4 から $74.5 \mathrm{mmHg}$ に低下した(Table 4)。酸・塩基平衡では酢酸透析と重炭酸透析の間には有 意差は認められなかった (Figure 2).

\section{3 愁訴発現頻度}

酢酸透析，重炭酸透析の両群共に愁訴としては血圧降 下が最も多くみられた。すなわち酢酸透析では2 251 回の 透析中 1075 回，47.8\%，また重炭酸透析では，4751 回 の透析中1479回，31.1\%にこれを認めたが両者を比較 すると䣷酸透析に有意に高率に認められた。そして透析 中の不快感では酢酸透析で 866 回，36.5\%，重炭酸透析 で 1188 回，25\%，筋ケイレンは酢酸透析で 318 回，14. $1 \%$ ，重炭酸透析では 488 回， $10.3 \%$ ，腹痛は酢酸透析 で 72 回， $3.2 \%$, 重炭酸透析で 84 回，1.8\%，嘔吐は酢
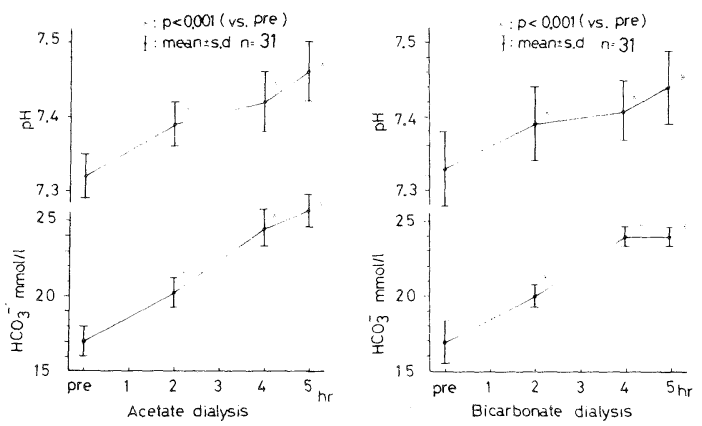

Fig. 2 Changes in blood $\mathrm{pH}$ and $\mathrm{HCO}_{3}^{-}$

\begin{tabular}{|c|c|c|c|}
\hline$P W$ (his) & $=1.3(0.8)$ & $51.3(0.9)$ & N.S \\
\hline ep $\begin{array}{l}\text { syst.(mmles) } \\
\text { diast. (" ) }\end{array}$ & $\left\{\begin{array}{l}133 \cdot 5(25,3) \\
79.4(16.2)\end{array}\right.$ & $\begin{array}{r}125.2(24.2) \\
74.5(14.6)\end{array}$ & $\begin{array}{c}p<0.001 \\
" 1\end{array}$ \\
\hline$\Delta B W \quad(k E)$ & $2.5(0.3)$ & $2.6(0.4)$ & N.S \\
\hline CTR $(\%)$ & $48.4(6.1)$ & $47.1(5.4)$ & $p<0.01$ \\
\hline RLIN $\left(m_{k}, d d\right)$ & $93.8(13.4)$ & $87.3(10.8)$ & $p<0.005$ \\
\hline $\mathrm{Cr}(n)$ & $13.8(2.6)$ & $13.2(2.6)$ & $"$ \\
\hline UA ( " ) & $10.4(1.4)$ & $8.0(1.2)$ & $p<0.001$ \\
\hline $\mathrm{Na}(\mathrm{meq} / 1)$ & $137.7(1.6)$ & $137.4(1.6)$ & $N \cdot S$ \\
\hline K ( $(")$ & $5.0(0.3)$ & $5.1(0.4)$ & $"$ \\
\hline Ca ( n) & $4.1(0.3)$ & $4.3(0.4)$ & $p<0.01$ \\
\hline $\mathrm{C} 1(")$ & $103.7(2.0)$ & $104.2(2.1)$ & N.S \\
\hline ip $(m g / d 1)$ & $6.3(0.9)$ & $6.5(0.8)$ & $"$ \\
\hline$T P(g / d l)$ & $7.3(0.4)$ & $7.4(0.4)$ & $"$ \\
\hline$R B C\left(10^{4} / \mathrm{mm}^{3}\right)$ & $234.4(43.9)$ & $253.1(62.7)$ & $p<0.005$ \\
\hline $\mathrm{WBC}\left(10^{3} / \mathrm{mm}^{3}\right)$ & $4.5(1.3)$ & $5.8(1.6)$ & N.S \\
\hline $\mathrm{Hb}(\mathrm{g} / \mathrm{dl})$ & $8.0(1.4)$ & $8.4(1.8)$ & $p<0.01$ \\
\hline Ht $(\%)$ & $22.9(4.5)$ & $24.8(5.8)$ & $p<0.001$ \\
\hline LDH (unit) & $319.7(47.9)$ & $273.6(48.4)$ & $"$ \\
\hline GOT ( $")$ & $28.7(14.2)$ & $22.6(9.5)$ & $"$ \\
\hline GPT ( " ) & $30.6(21.2)$ & $22.8(15.6)$ & $"$ \\
\hline AIp ( $")$ & $17.2(11.7)$ & $16.8(12.3)$ & N.S \\
\hline $\mathrm{TG}(\mathrm{mg} / \mathrm{dl})$ & $149.8(58.1)$ & $130.0 \quad(73.6)$ & $"$ \\
\hline TC $1 " n)$ & $168.8(32.4)$ & $170.5(34.1)$ & $"$ \\
\hline GLU $(n)$ & $105.9 \div 8.6)$ & $104.4(11.6)$ & $"$ \\
\hline
\end{tabular}

mean ( s.d) $n=31$

Table. 4 Comparison of Laboratory Data between Acetate Dialysis and BicarDialysis

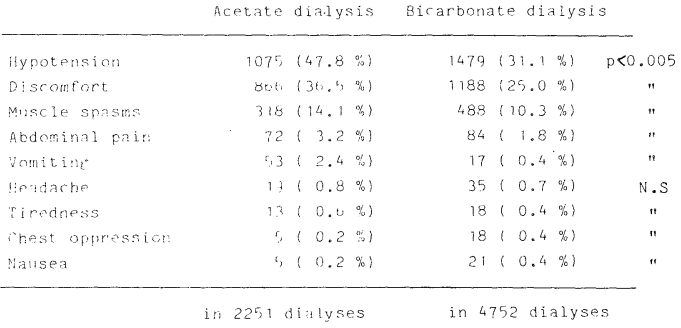

Table. 5 Incidence of Morbidity during. Dialysis with Acetate versus Bicarbonate Dialysata

酸透析で 53 回，2.4\%，重炭酸透析 17 回，0.4\%といず れも酢酸透析で有意に多く認められた.透析中の疲労感， 胸内苦悶, 頭痛, 嘔気に関しては有意差を認めなかった。 これら症状の程度は酢酸透析と重炭酸透析の間では差は なかった。また 31 例の透析前体重は酢酸透析施行時で $51.3 \pm 6.8 \mathrm{~kg}$ ，重炭酸透析施行時で $51.3 \pm 6.9 \mathrm{~kg}$ であ り, 除水量は酢酸透析施行時で $2.5 \pm 0.3 \mathrm{~kg}$, 重炭酸透析 施行時で $2.6 \pm 0.4 \mathrm{~kg}$ で有意差は認められなかった

(Table 5). 
42 重盲検交差試験

透析液を重炭酸透析液加ら酢酸透析液に転換すること により 56 例中 34 例，61\%（Table 1 患者 1 34) に何 らかの愁訴が新たに発現した。そして 12 例， $21 \%$ (患者 23〜34）ではその症状が激しく，透析時間を短縮せざる を得なかった。残る22 例（患者 35〜 56）には変化を認め なかった。患者の内わけは愁訴発現例では女子の占める

\begin{tabular}{ccccc} 
& Age (yrs) & $\begin{array}{c}\text { Duration of } \\
\text { dialysisimos) }\end{array}$ & $\begin{array}{c}\text { B.W } \\
\text { (kg) }\end{array}$ & $\begin{array}{c}\Delta B . W \\
\text { (kg) }\end{array}$ \\
\hline $\begin{array}{c}\text { Symrtomatic cases } \\
\text { No. 1 No.34 }\end{array}$ & $43.2 \pm 11.5$ & $42.7 \pm 19.7$ & $46.9 \pm 7.9^{*}$ & $2.1 \pm 0.6^{*}$ \\
$\begin{array}{c}\text { Symptomatic cases } \\
\text { No.23 - No.34 }\end{array}$ & $45.5 \pm 11.2$ & $41.0 \pm 20.0$ & $48.6 \pm 4.3$ & $2.0 \pm 0.6^{*}$ \\
Asymptomatic cases \\
No.35 - No.56 & $41.7 \pm 8.0$ & $44.4 \pm 29.9$ & $51.4 \pm 7.8$ & $2.7 \pm 0.9$ \\
\hline
\end{tabular}

* : p<0.05 (varsus asymptomatic cases)

R.W : Body weipht before dialysis

$A R, W$ : Body weight loss during dialysis

Table. 6 Characteristics of the Symptomatic and Asymptomatic Cases

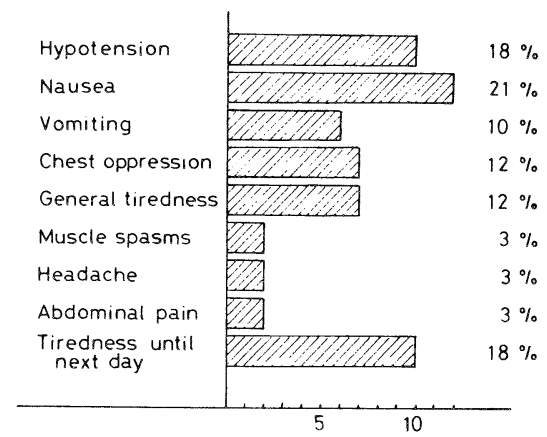

Fig. 3 Incidence of morbidity due to converting of bicarbonate dialysate to acetate dialysate on double blind test
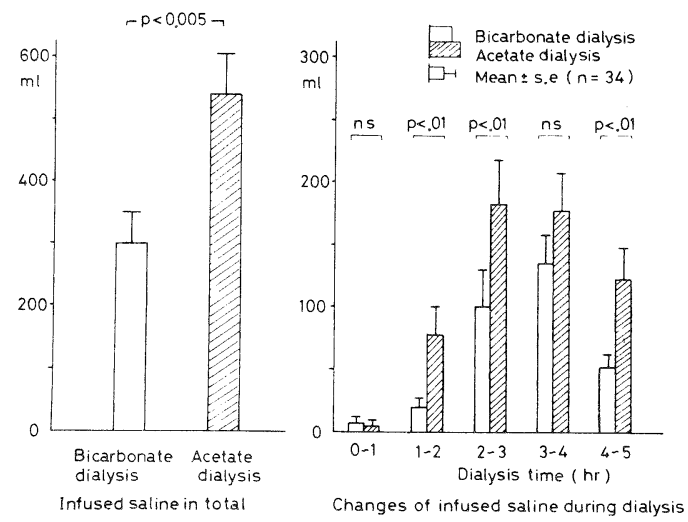

Fig. 4 Comparison of amount of infused saline between bicarbonate and acetate dialy. sis on double blind test
割合が多く, 23 例，68\%であり，透析時間短縮例では 11 例, $92 \%$ であった。一方. 愁訴の発現をみなかった例で は女子の割合は 4 例，18\%であった。またこれら患者群 間の年齢, 透析期間には有意差はなく, 透析前体重, 除 水量では愁訴発現群で有意に低かった(Table 6)。発現 した愁訴の比較では嘔気が $21 \%$ で最も多く, 次に血圧降

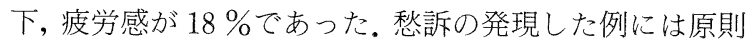
的に生食液の注入を行ない, その注入量の比較では総量, 時間的推移共に酢酸透析に多かった (Figure 3, 4).

\section{5 酢酸移行量測定}

酢酸透析で HFAK $1.1 \mathrm{~m}^{2}$ を使用すると酢酸の体内移 行量は $3.47 \pm 0.50 \mathrm{mmol} / \mathrm{hr} / \mathrm{kg}$ である。そして HFAK 2 . $1 \mathrm{~m}^{2}$ では $4.48 \pm 0.82 \mathrm{mmol} / \mathrm{hr} / \mathrm{kg}$ である。一方，重炭酸 透析における酢酸の移行量は HFAK $1.1 \mathrm{~m}^{2}$ で $0.41 \pm 0$. $08 \mathrm{mmol} / \mathrm{hr} / \mathrm{kg}$, HFAK $2.1 \mathrm{~m}^{2}$ で $0.72 \pm 0.09 \mathrm{mmol} / \mathrm{hr} /$ $\mathrm{kg}$ であり,生体内に入る酢酸の量は重炭酸透析で極めて 少量であった（Table 7)。

\begin{tabular}{|c|c|c|c|c|}
\hline & \multicolumn{2}{|c|}{ Acetate dialysis } & \multicolumn{2}{|c|}{ Bicarbonate dialysis } \\
\hline & HFAK $-1.1 \mathrm{~m}^{2}$ & HFAK $-2,1 \mathrm{~m}^{2}$ & HFAK $-1.1 \mathrm{~m}^{2}$ & $H F A K-2.1 m^{2}$ \\
\hline $\begin{array}{l}\text { Loaded acetate } \\
\text { mmol/hr }\end{array}$ & $162(27)$ & $238(19)$ & $19.3(2.4)$ & $39.0(5.1)$ \\
\hline $\mathrm{mmol} / \mathrm{hr} / \mathrm{kg}$ & $3.47(0.50)$ & $4.48 \quad(0.82)$ & $0.41(0.08)$ & $0.72(0.09)$ \\
\hline Dialysis hours & 5 & 4 & 5 & 4 \\
\hline & $n=14$ & $n=6$ & $n=5$ & $n=3$ \\
\hline
\end{tabular}

Table 7 Net Load of Acetate during Dialysis

\section{考察}

重炭酸透析液の構成は $\mathrm{H}_{2} \mathrm{CO}_{3}$ と $\mathrm{NaHCO}_{3}$ の濃度比 により決定し，また $\mathrm{H}_{2} \mathrm{CO}_{3}$ は液の $\mathrm{PCO}_{2}$ と共に変化す る. 重炭酸透析液の安定性はすなわち, 液の $\mathrm{CO}_{2}$ 含量で あり，いかに $\mathrm{PCO}_{2}$ を調整するか，そして $\mathrm{Ca}, \mathrm{Mg}$ 等の 沈殿をいかに処理するかが問題となる、液の $\mathrm{PCO}_{2}$ の調 整には一般的に $\mathrm{CO}_{2}$ ガスの bubbling, 酸の添加等が行 なわれるが, 酸添加の場合, $\mathrm{HCl}$ を使用すると 35 倍希釈 後の $\mathrm{HCl}$ 濃度は理論上 $3 \mathrm{mmol} / l$ 程度必要であり, 原液 に $\mathrm{HCl}$ を加える場合には $105 \mathrm{mmol} / l$, すなわち $\mathrm{pH} 1$ 〜2の原液を使用しなければならない.これは透析器機 の耐久性の問題等で好ましくない。今回，我々の使用し た重炭酸透析液は酸として $\mathrm{CH}_{3} \mathrm{COOH}$ を含み，また同時 に $\mathrm{CH}_{3} \mathrm{COONa}$ を添加して，その緩衝作用により原液 $\mathrm{pH}$ を 4 亿に調整でき，製剤化を可能にしたものであ る. $\mathrm{CH}_{3} \mathrm{COOH}$ と $\mathrm{CH}_{3} \mathrm{COONa}$ の濃度比は約 $1 ： 2$ であ り, 酢酸の総含量としては, 約 $9 \mathrm{mmol} / l$ となる。Table 3 に示したように, $\mathrm{PCO}_{2}$ は mixing tank から reservoir 間で約 $13 \mathrm{mmHg}$ の低下を示すが，これは mixing tank での急激な攪找による $\mathrm{CO}_{2}$ の大気中への放散のためと 
考えられる. reservoir から bed sideまでは約 $15 \mathrm{~m}$ の配 管であるが,この間は安定している。また Ca 濃度に関し ては特に問題はなかった。透析液の $\mathrm{pH}$ は低いほど,この 沈殿の問題は減少するが, 極端に低くない限り, 透析液 として充分使用できる。例えば $\mathrm{NaHCO}_{3}$ 濃度 $30 \mathrm{mmol} /$ $l$ の透析液に酸を添加して $\mathrm{pH} 7.4$ の液と $\mathrm{pH} 7.0$ の液を 調整した場合, $\mathrm{pH} 7.4$ の液の $\mathrm{H}_{2} \mathrm{CO}_{3}$ 濃度は約 $1.5 \mathrm{mmol} /$ $l, \mathrm{pH} 7.0$ の液は約 $3.0 \mathrm{mmol} / l$ であり, いま血液中の $\mathrm{H}_{2}$ $\mathrm{CO}_{3}$ 濃度を 0 ，そして $\mathrm{H}_{2} \mathrm{CO}_{3}$ が透析膜をすべて拡散す るとして，5 時間透析 (血液流量 $200 \mathrm{~m} / / \mathrm{min}$ ) では, 前 者は $90 \mathrm{mmol}$ ，後者は $180 \mathrm{mmol}$ の $\mathrm{H}_{2} \mathrm{CO}_{3}$ が生体内に 移行することになる。いまこの酸の中和のために単純に $90 \mathrm{mmol} の$ 余分の緩衝物質を必要としても生体にとつ ては大した量ではないし，また実際にはこれ程の量が負 荷されることはない。このような考えから我々は重炭酸 透析液の $\mathrm{pH}$ は 7.2 付近で調整している. $\mathrm{pH} 7.0$ 付近で も酸・塩基平衡に関しては大差はないが，調整幅，変動 幅等の問題，また heparinの活性低下等の報告 ${ }^{5)} も あ り ，$ $\mathrm{pH} 7.2$ 付近が好ましいと考えている。またいかに $\mathrm{pH}$ が 低くても $\mathrm{Ca}, \mathrm{Mg}$ 塩等の沈殿は必ず生じるものであり, 装置の洗滌等には工夫が必要である。器機の腐触等によ る重金属污染にも注意が必要である ${ }^{3}$. 以上のように重炭 酸透析液には理論上 $9 \mathrm{mmol} / \mathrm{l}$ の酢酸を含んでいるが, Table 7 に示したように, 酶酸移行量は HFAK $2.1 \mathrm{~m}^{2}$ で も $0.72 \pm 0.09 \mathrm{mmol} / \mathrm{hr} / \mathrm{kg}$ であり,この程度の移行量で あれば, 生体は充分に代謝でき ${ }^{6) 88}$ ，透析中の酢酸濃度は 上昇することはない ${ }^{9}$.また酢酸移行量は必ずしも䣷酸濃 度に比例することなく, $9 \mathrm{mmol} / l$ の濃度では実際の濃 度勾配よりも低くなる。これは, 酢酸 ion と重炭酸 ionに 抢ける拡散係数の差による効果と考えられる ${ }^{10)}$.このよ うに移行した少量の䣷酸ion は体内では臨床症状に全く 影響を与えることなく完全に代謝され，有効な緩衝㨈と なる。従って少量の酢酸ionの存在はむしろ重炭酸透析 の安定性を増し, 生体に大きな負荷とならず, その使用 は好ましいと考えられる。

重炭酸透析液を実際に使用して, 酢酸透析液と比較し, 最も大きな違いは透析中の愁訴の少ないことである．特 に血液透析導入期の患者, 重症の患者には穏やかな透析 が施行できることをしばしば経験している，我々の今回 行なった 2 重盲検交差試験は $60 \%$ 以上の患者に何らかの 愁訴発現をみて抢り,そして $20 \%$ の患者は酢酸透析に対 して不適応であった。酢酸が透析中の愁訴にどのように 影響しているか明らかではないが, 末梢血管抵抗の減少, 心管抑制作用 ${ }^{11)}{ }^{12}$ ，脳脊䯚液や脳血液関門の問題 ${ }^{13)}{ }^{14)}$ 等 が報告されている。我々は透析中に血中酢酸濃度の上昇 した例でも，急激な血圧降下なしに強い愁訴の発現した
場合のあることから ${ }^{15)}$, 酢酸の過剰投与より生じる一時 的な代謝異常による全身的な症状と考元ている。この酢 酸の代謝異常に関してはEgan は血清中と細胞表面に阻

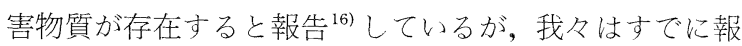
告 ${ }^{17)}$ したように, 酢酸の代謝の TCA-cycle での律速過 程に存在すると考えている.

臨床検查成績の長期比較では重炭酸透析に扎いて, BUN , Cr，UA が有意に低下し，貧血の改善がみられた が，これは重炭酸透析により，副作用のより少ない透析 を施行でき, 透析の効率が上昇したためと思われる。 GOT，GPT，LDH に関しても低下傾向を示した。酢酸 はその代謝の場を主として筋組織の mitochondria 内に もっているので,肝での役割は少ないが ${ }^{18)}$, 過㮃に投与さ れた場合には肝は重要な役割をもっている。従って，こ の点から酢酸の過剩負荷のない重炭酸透析は肝機能の維 持に有利と考えられる。長期比較による血中脂質の変化 は今回の研究でも認められなかったが，今後これらも合 わせ検討されなければならないことと考えている。

以上のごとく，透析液に使用されている酶酸が何らか のかたちで透析中の不快な症状をひきおこしていること は, 我々の成績から充分示唆される。また現在, 市販さ れている酰酸透析液を用いて，一層透析効率のすぐれた 透析器を使用するならば，流入する酶酸による愁訴の発 現は増加し, 重炭酸透析の適応が更に増大すると考えら れる。このような観点から，短時間透析を実施する上で も，重炭酸透析は重要な手段になると思わ机る。そして 透析患者の増加および長期化に伴う合併症の改善，また その管理の容易さから, 無症状透析の必要性が強く要望 されている。

\section{結論}

1. 重炭酸透析液（キンダリー AF 号）について，多 人数用重炭酸透析液供給装置での安定性を調べた結果, $\mathrm{pH}, \mathrm{PCO}_{2}$ 共に至適值に調整されて抢り, $\mathrm{Ca}$ 濃度にも変 化なかった。

2. 䣷酸透析と重炭酸透析における臨床検查成績の比 較を行ない, 重炭酸透析導入により BUN, Cr, UA, $\mathrm{RBC}, \mathrm{Hb}, \mathrm{Ht}, \mathrm{GOT}, \mathrm{GPT}, \mathrm{LDH}$ に有意の改善がみ られた。

3. 重炭酸透析と酷酸透析の 2 重盲検交差試験を行な い, また重炭酸透析と酢酸透析での愁訴発現頻度の検討 を行なったところ，重炭酸透析は症状の少ない透析とい う点で酢酸透析に比し,より有効であることが示された。

4. キンダリー AF 号の酶酸濃度は透析患者の体内で 充分代謝できる程度の酢酸量であることが示された。

5. 重炭酸透析の 32 か月間の使用中, 特に副作用と思 わ机ることは認めなかった。 
本論文の要旨は第 22 回日本腎臓学会において発表し た。な㧍，本研究に扔いて透析液の供給に協力頂いた扶 桑薬品工業株式会社に感謝する。

\section{文献}

1) Novello, A., Kelsch, R.C., Easterling, R.E. : Acetate intolerance during hemodialysis, Clin. Nephrol. 5 : 29-32, 1976.

2) Tolchin, N., Roberts, J.L., Hayashi, J., Lewis, E. J. : Metabolic consequences of high mass-transfer hemodialysis, Kidney Int. 11:366-378, 1977.

3）山本忠司, 山川真, 水谷洋子, 岡田上茂, 前川正信, 岸本武利, 西島高明: Bicarbonate dialysate による 多人数用供給装置について, 人工臟器 $7: 298-300$, 1978.

4) Boček, P., Lekova, K., Deml, M., Janák, J. : Separation of some typical Krebs cycle acids by high-speed isotachophoresis, J. Chromatogr. 117 : 97-104, 1976.

5) Schwarzbeck, A., Wagner, L., Squarr, H.U., Strauch,M. : pH-dependent heparin inactivation during hemodialysis, Dial. Transplant. $7: 740$ 742, 1978.

6) 山川真, 山本忠司, 水谷洋子, 堀内延昭, 平田純生, 足利和子, 中山富子, 前川正信, 岸本武利, 中西純 造, 松村俊宏, 西島高明, 佐谷誠: 透析液中の acetateの透析患者への影響, 人工透析研究会会誌 11:291-294, 1978.

7) Lundquist, F. : Production and utilization of free acetate in man, Nature $193:$ 579-580, 1962.

8) Kveim, M., Nesbakken, R. : Utilization of exogenous acetate during hemodialysis. Trans. Am. Soc. Artif. Int. Organs 21 : 138-143, 1975.

9) Kishimoto, T., Yamakawa, M., Mizutani, Y., Yamamoto, T., Hirata, S., Horiuchi, N., Tanaka, H., Maekawa, M. : Morbidity, instability and serum acetate level during hemodialysis. Artificial Organs, in press.

10) Wingert, K.J., Weiner, M.W. : Acetate transfer across membranes of artificial kidneys in vitro. Kidney Int., 15 : 593-600, 1979.

11）相沢義房, 柴田昭, 大森伯, 平沢由平：透析液中の アセテートの心血管系への作用, 日腎誌 $20 ： 1167-$ $1172,1978$.

12) Kirkendol, P.L., Devia, C.J., Bower, J.D., Holbert, R.D. : A comparison of the cardiovascular effects of sodium acetate, sodium bicarbonate and other potential sources of fixed base in hemodialysate solutions, Trans. Am. Soc. Artif. Intern. Organs $23: 399-405,1977$.

13) 天野泉, 稲垣豊, 加納薰, 大野秀作, 杉山敏, 太田 裕祥, 小川秋広, 広瀬正美, 高橋源作: 不均衡症候 群に対する acetate free 透析液の効果について，人 工透析研究会会誌 $11 ： 287-290,1978$.

14）永井賢一：透析液 acetate 及び bicarbonate の症状 への影響, 人工透析研究会会誌 $12: 1057-1058$, 1979.

15）水谷洋子, 山本忠司, 平田純生, 堀内延昭, 野崎寛 爾, 山川真, 田中寛, 岸本武利, 前川正信: 透析液 中の Na-acetate の影響 (第 4 報) 一透析中の不快愁 訴と血中 acetate 濃度との関連性について一, 人工 透析研究会会誌 $12 ： 1055-1056,1979$.

16) Egan, J.D., Wells, I.C. : Acetate intolerance and an inhibitor of acetate utilization in hemodialysis patients, Clin. Chem. 25 : 379-383, 1979.

17）山本忠司, 堀内延昭, 平田純生, 野崎寛爾, 水谷洋 子, 山川真, 田中寬, 岸本武利, 前川正信: 血液透 析中の Na-acetate の影響, TCA-cycle 中間代謝物 の血中濃度について, 術後代謝研究会誌 $14: 32-35$, 1980 .

18) Ballard, F.J. : Supply and utilization of acetate in mammals. Am. J. Clin. Nutr. 25 : 773-779, 1972. 